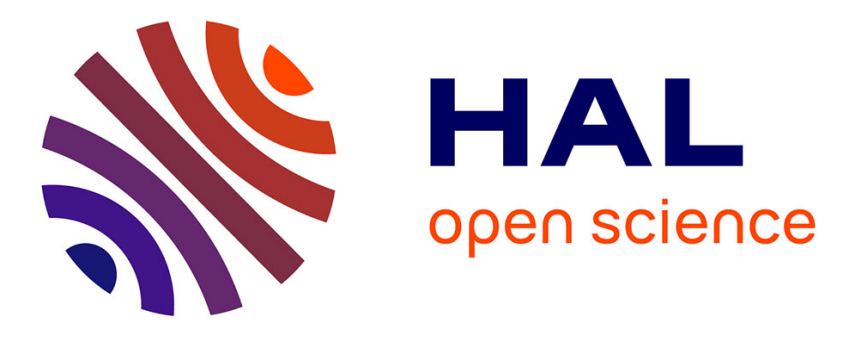

\title{
Dispositioning Strategies of Maintenance Tasks in Offshore Wind Farms
}

\author{
Felix Optehostert, Daniela Müller, Philipp Jussen
}

\section{To cite this version:}

Felix Optehostert, Daniela Müller, Philipp Jussen. Dispositioning Strategies of Maintenance Tasks in Offshore Wind Farms. IFIP International Conference on Advances in Production Management Systems (APMS), Sep 2017, Hamburg, Germany. pp.101-108, 10.1007/978-3-319-66923-6_12 . hal01666221

\section{HAL Id: hal-01666221 \\ https://hal.inria.fr/hal-01666221}

Submitted on 18 Dec 2017

HAL is a multi-disciplinary open access archive for the deposit and dissemination of scientific research documents, whether they are published or not. The documents may come from teaching and research institutions in France or abroad, or from public or private research centers.
L'archive ouverte pluridisciplinaire HAL, est destinée au dépôt et à la diffusion de documents scientifiques de niveau recherche, publiés ou non, émanant des établissements d'enseignement et de recherche français ou étrangers, des laboratoires publics ou privés. 


\title{
Dispositioning Strategies of Maintenance Tasks in Offshore Wind Farms
}

\author{
Felix Optehostert, Daniela Müller, Philipp Jussen \\ Institute for Industrial Management at RWTH Aachen University, Campus-Boulevard 55, \\ 52074 Aachen, Germany \\ \{Felix.Optehostert, Daniela.Mueller, Philipp.Jussen\}@fir.rwth- \\ aachen. de
}

\begin{abstract}
Operation and Maintenance (O\&M) is a key value driver for offshore wind farms. Consequently, reducing O\&M costs improves their profitability. This paper introduces different typologies of dispositioning maintenance tasks in offshore wind farms, in order to help design the strategies and organization of maintenance. Based on the special requirements of offshore wind farms regarding planning and controlling the O\&M activities, a morphological analysis was developed. With this different disposition strategies for offshore wind farms could be generated. The consequences of choosing different characteristics are allegorized in an exemplary fashion. The work presented in the following is the foundation for designing a software-based dispositioning tool for usage in offshore wind farms, which will help to increase the effectiveness of the disposition in offshore wind farms by maximizing the number of accomplished tasks per day and minimizing the time technicians stay on the wind turbine and the ships.
\end{abstract}

Keywords: Tool Asset Management, Operation and Maintenance, Disposition, Offshore Wind Farms

\section{Introduction}

Improving the profitability of offshore wind farms is essential for a successful and sustainable energy turnaround. However, in relation to other energy sources offshore wind farms are still not as competitive. This becomes obvious when comparing the levelized cost of energy (LCOE), a key performance indicator for profitability of energy sources (Figure 1. Levelized Cost of Energy [1]). The LCOE depicts the costs of power production respective to the expected operating life of a power plant. This calculation considers the total lifetime cost, such as discounted capital costs, overheads and expenses for fuel divided by the lifetime discounted electricity outcome. As it can be seen in Figure 1 the LCOE for offshore wind farms exceed the LCOE for any other energy source.

To achieve a competitive advantage, the LCOE must be reduced. There are defined levers to do so, such as optimizing the O\&M processes and organization, which consumes $28 \%$ of the [overall] lifecycle costs [2]. Consequently, O\&M is a key value driver 
and crucial for improving the profitability of offshore wind farms. For example, a reduction of $10 \%$ O\&M costs leads to an advance of $4 \%$ of earnings before interest and taxes (EBIT). An improvement of $1 \%$ of availability would lead to an increase of the EBIT by $2 \%$ [2].

Reducing O\&M costs by optimizing the disposition efficiency is the overall goal of this study. Typologies of the disposition of maintenance tasks in offshore wind farms will be introduced. These typologies help to design the maintenance organization and determine the task and resource planning strategies. Effectively, it is used to design a software that plans and dispositions the tasks and resources in offshore wind farms. This software tool was developed as a prototype in the research project DispoOffshore, funded by the German Federal Ministry for Economics.

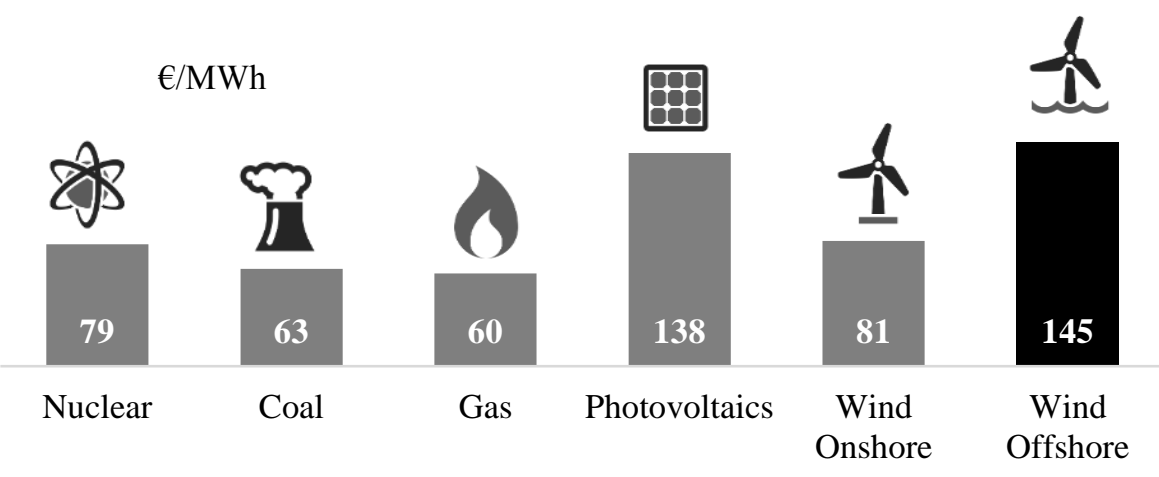

Fig. 1. LOCE [1]

\section{Maintenance in Offshore Wind Farms}

The maintenance of offshore wind farms requires different standards and is more challenging than onshore maintenance. Those challenges and standards must be considered when designing disposition strategies for the maintenance operations.

Offshore wind farms are not easy to access, as they are placed several kilometers off shore and from the service hub. Therefore, vessels have to drop off the technicians by performing precise maneuvers. Additionally there is no access to the wind turbines when, due to bad sight or huge wave heights from the weather conditions, vessels cannot safely travel [3]. The efficiency of a daily working plan is therefore dependent on the ideal allocation of maintenance tasks to service technicians and vessels. This assignment determines whether the routes of the vessels are optimal and whether the appropriate technician with the required qualifications will finish all necessary tasks. If this assignment is not performed in an optimum fashion, the vessels will have insufficient routes and too few tasks for the estimated working hours each day. These considerations apply to designing the working plan of each day.

Previous work in this field suggests different approaches on planning and control of tasks and resources. In relation to this paper, methods of production economics and service management were examined. The Production Planning and Control Model 
(PPC-model) addresses the termination of problems and allocations of production services and resources [4]. This approach minimizes processing time needed to plan more tasks with limited resources (here: workers). To deal with the problem of combined tours and personnel planning within short time windows, ZÄPFEL and BöGL came up with multi-period vehicle routing and crew scheduling with outsourcing options. The strategy considers different vehicles with variable capacities and outsourcing options for tours and external staff [5]. The Product Service System (PSS) capacity planning, by KRUG, schedules the performance of PSS close to optimum. One part of this concept is the prediction of future service dates and the warrant resources [6]. IRAWAN developed a strategy to optimize maintenance routing and scheduling for offshore wind farms. They also proposed a solution method based on a Dantzig-Wolfe decomposition of the problem, which strived to find the optimal route that minimizes maintenance costs [7]. STÅLHANE evolved a method for the similar purpose of optimizing the routing and scheduling of vessels to perform maintenance at offshore wind farms. On the other hand, two alternative models of optimization were assessed: an arc-flow and a pathflow [8].

None of the previously mentioned approaches meets all requirements for the dispositioning in offshore wind farms on an operational level. The research by IRAWAN and STÅLHANE are most relevant to this paper. However, they do not take into consideration the staff's qualification, organizational circumstances nor a prioritization of the tasks, as an important part of the disposition on an operational level.

\section{Disposition Strategies of Maintenance Tasks and Resources in Offshore Wind Farms}

Based on the special requirements of offshore wind farms, a morphological analysis of the disposition of maintenance tasks in offshore wind farms is introduced. This analysis can be used to design the maintenance processes and disposition strategies for the offshore wind farm's maintenance organization.

\subsection{The Morphological Analysis}

The morphological analysis (or box) was the chosen technique to identify and evaluate the imposed requirements of offshore wind farms. As there are complex restrictions for the maintenance organization of offshore wind farms, it is hard to identify a solution which meets all requirements. The morphological box depicts all the requirements while helping to determine the best disposition strategy.

The morphological analysis was first introduced by ZWICKY, showing the totality of conceivable solutions for a problem. First, the problem is defined, analyzed, and generalized to partial aspects. These partial aspects are classified with independent parameters, which can apply to all possible solutions. After this, the parameters are specified with their characteristics. All parameters must be depicted in the morphological box, the dimensions of which equal the characteristics. All possible solutions have to be assessed and evaluated without prejudice before the final decision can be made [9]. 
The morphological analysis is suitable to describe complex structures by organizing the tokens of dispositioning. By doing so, the parameters must fulfill the following criteria: purpose significance, ability to ascertain, differentiability, integrity, ability to quantify, and independence from one another [10-12]. In the following, a morphological analysis for the dispositioning strategies in offshore wind farms is introduced.

\subsection{Morphological Analysis of Wind Farm Specific Requirements}

The morphological analysis was performed throughout interviews and surveys with experts in the field of dispositioning tasks for offshore wind farms. The results of these expert interviews were partitioned into 4 categories, which cover 26 parameters. These parameters can apply to a variety of feasible solutions, and each are specified with 2 to 7 characteristics.

These categories involve the "Sequence of dispositioning steps", "Prioritizing and optimizing", "Assignment team and means of transport" and "Weather", all described in the following.

The category "Sequence of dispositioning steps" contains all of the steps needed to assign tasks to the respective qualified person or resource, assemble the teams, and assign the means of transport (Figure 2). The chronology of these steps can vary and therefore influences the outcome of the disposition strategy. The allotted number determines on which position, within the heuristic, the respective assignment step would be.

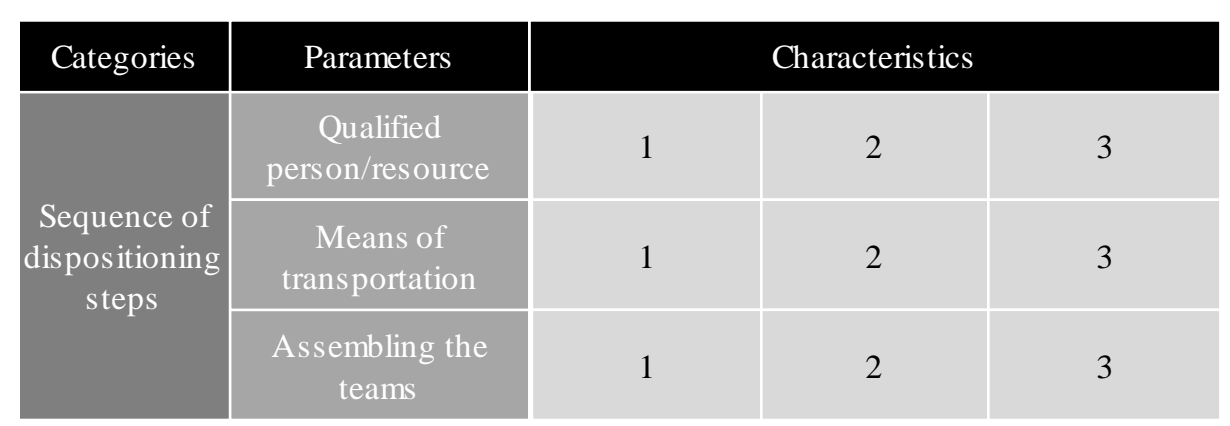

Fig. 2. Sequence of dispositioning steps

The category "Prioritizing and optimizing" determines whether the tasks were preselected during preparation, whether the tasks were allocated manually, automatically, or semiautomatically, and whether the tasks are divided into subtasks ad recombined to task bunches (Figure 3). Furthermore, parameters for the prioritization of tasks found in the task repository and the optimization of criterion for the algorithm are incorporated in this category. Either the due dates, locations, first-in-first-out principal or their urgency, which can be related to opportunity costs by not operating wind turbines, can prioritize tasks. This prioritization influences the order of the tasks in the repository. To receive the optimal task disposition, the algorithm needs a criterion to optimize. The criteria meet targets, such as making full use of the ships' or teams' workload, utilizing 
shorter routes, lowering costs, minimizing the preparation time, the shortest overall duration or maximizing the quantity of disposed tasks.

\begin{tabular}{|c|c|c|c|c|c|c|}
\hline Categories & Parameters & \multicolumn{5}{|c|}{ Characteristics } \\
\hline \multirow{4}{*}{$\begin{array}{l}\text { Prioritizing } \\
\text { and } \\
\text { optimizing }\end{array}$} & $\begin{array}{c}\text { Process of task } \\
\text { allocation }\end{array}$ & Manual & Auto & matic & Semi & utomatic \\
\hline & $\begin{array}{l}\text { Fission and } \\
\text { recombination } \\
\text { of task bunches }\end{array}$ & \multicolumn{2}{|c|}{ Yes } & \multicolumn{3}{|c|}{ No } \\
\hline & \begin{tabular}{|c}
$\begin{array}{c}\text { Prioritizing the } \\
\text { tasks }\end{array}$ \\
\end{tabular} & Urgency & Due date & Location & & $\begin{array}{l}\text { First in } \\
\text { first out }\end{array}$ \\
\hline & $\begin{array}{l}\text { Optimizing } \\
\text { algorithm }\end{array}$ & $\begin{array}{l}\text { Minimizing } \\
\text { set-up time }\end{array}$ & $\begin{array}{c}\text { Ves sel/team } \\
\text { utilization }\end{array}$ & $\begin{array}{c}\text { Shortest } \\
\text { overall } \\
\text { duration }\end{array}$ & $\cdots$ & $\begin{array}{l}\text { Quantity } \\
\text { of tasks }\end{array}$ \\
\hline
\end{tabular}

Fig. 3. Prioritizing maintenance tasks

The category "Assignment teams and means of transport" determines all aspects that are needed for the team allocation. Figure 4 shows alternative options regarding the means of transport as a part of this category. This selection can be made manually, semi- or full-automatically, but there are also different options within the means of transport themselves. Either a helicopter or a ship can be used. Although the helicopter requires less time to reach the wind farm, it is more expensive than a ship transfer. However, this is only necessary for urgent repairs during weather conditions the ships cannot handle.

\begin{tabular}{|c|c|c|c|c|c|}
\hline Categories & Parameters & \multicolumn{3}{|c|}{ Characteristics } \\
\hline \multirow{2}{*}{$\begin{array}{c}\text { Assignment } \\
\text { teams and } \\
\text { means of } \\
\text { transport }\end{array}$} & $\begin{array}{c}\text { Meams of allocation } \\
\text { transport }\end{array}$ & Manual & Automatic & Semiautomatic \\
\cline { 2 - 5 } & $\begin{array}{c}\text { Teams not restricted } \\
\text { to one ship } \\
\text { between wind } \\
\text { farm and } \\
\text { service hub }\end{array}$ & $\begin{array}{c}\text { No shuttle } \\
\text { between wind } \\
\text { farm and } \\
\text { service hub }\end{array}$ & $\begin{array}{c}\text { Teams } \\
\text { restricted to } \\
\text { one ship }\end{array}$ & $\begin{array}{c}\text { Heli- } \\
\text { copter }\end{array}$ \\
\hline
\end{tabular}

Fig. 4. Team assembling and means of transport

The last category, "Weather", displays if certain weather characteristics are considered in the distribution (Figure 5). This covers the wind direction, wave height, restricted sight (due to fog or night time), and tide. 


\begin{tabular}{|c|c|c|c|}
\hline Categories & Parameters & \multicolumn{2}{|c|}{ Characteristics } \\
\hline \multirow{3}{*}{ Weather } & Wind direction & Yes & No \\
\cline { 2 - 4 } & Wave height & Yes & No \\
\cline { 2 - 4 } & Restricted sight & Yes & No \\
\cline { 2 - 4 } & Tide & Yes & No
\end{tabular}

Fig. 5. Weather

\subsection{Disposition Strategy Development}

A disposition strategy is an approach to make fast disposition decisions with justifiable expenditure for the purpose of the striven for targets [13]. Based on the morphological analysis, described in the previous section, different disposition strategies for offshore wind farms can be designed. This can be achieved by choosing a specific path through the morphological box.

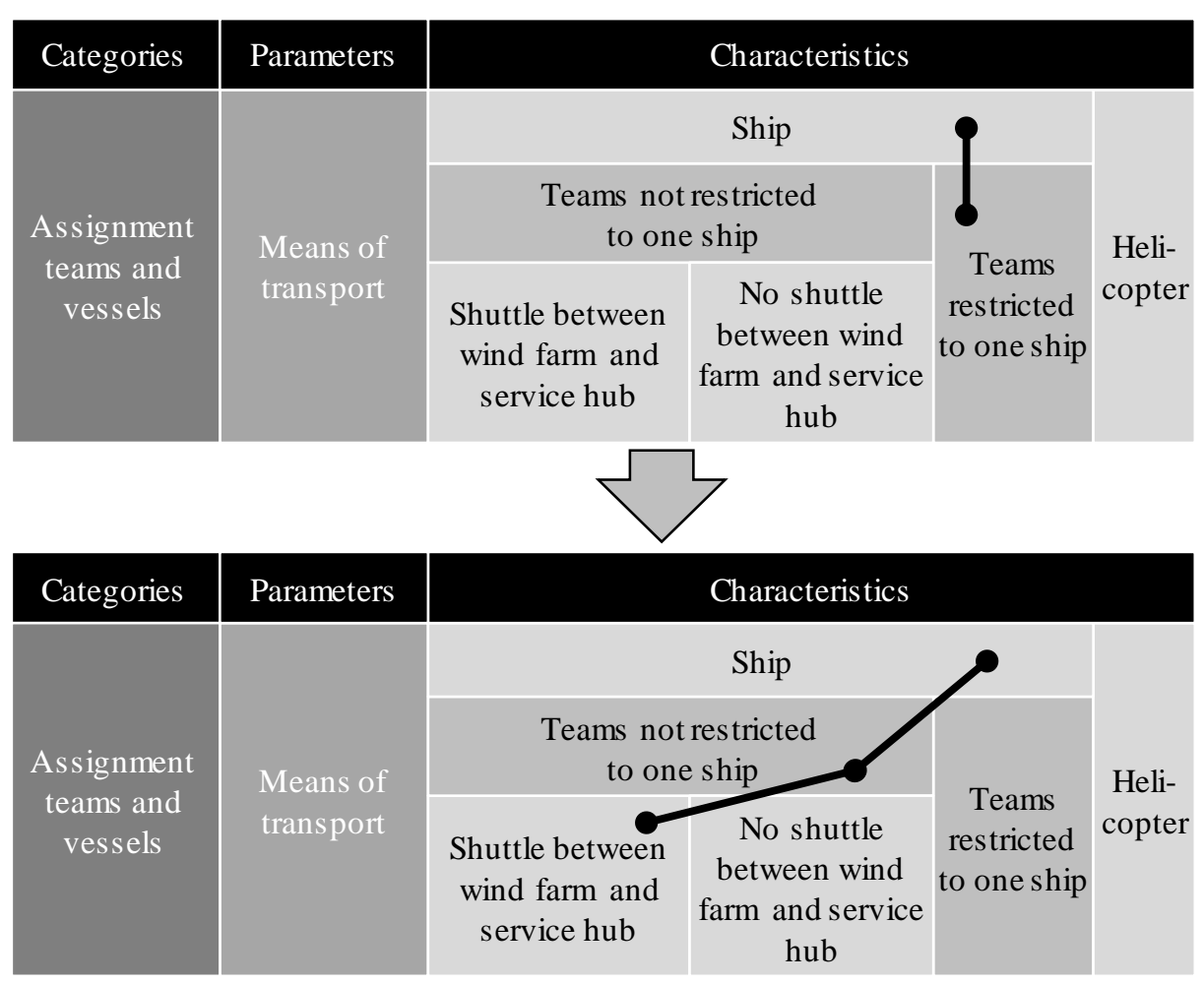

Fig. 6. Means of transport 
The tasks are defined by several attributes, such as the assumed time the technicians need to accomplish the task, the due date to make sure that the guarantee does not expire, and the priority measured by urgency such as troubleshooting over regular maintenance and rectification of defects to inspections. A list of required qualifications confines the variety of teams and means of transport. In addition, lists with needed material and tools, as well as the location of the task, whether it is on a wind energy plant and the platform, are part of a task's characterization. Changes in characteristics of a parameter lead to different disposition strategies. The relevant characteristics depend on the operational procedures for maintenance of the considered wind farm.

Two examples: As there are only six food boxes available per wind turbine the maximum number of people on a turbine is set to six. These boxes contain supplies for workers in case recovery is not possible at that time. This needs to be considered when assigning tasks to the technician teams on the same wind turbine.

Additionally, altering the choice for means of transport has a significant effect on the disposition too, as displayed in Figure 6. Using a ship offers two different opportunities of usage. A so-called "taxi service", which does not restrain the teams to the use of only one ship, allows the team to use any vessel in the wind farm on demand. Using a so-called "shuttle service" links the teams to a certain ship which has a predefined route through the wind farm. Figure 6 illustrates the alternation between a "shuttle service" to a "taxi service". These modifications have a decisive effect on the disposition software, effects on the time the teams spend on one ship and how many ships are in use.

It becomes obvious that by altering the boundary conditions and characteristics, the disposition strategy changes.

\section{Conclusion}

Introduced was a morphological analysis, which enables a systemic approach to design the disposition strategy of offshore wind farms. This morphological analysis was acquired by interviews and surveys with experts in the field of dispositioning tasks for offshore wind farms and based on the special requirements of offshore wind farms regarding the maintenance organization, planning, and control. The results show 4 parameter categories, which cover 26 parameters. These parameters can apply to a variety of feasible solutions and are specified with each 2 to 7 characteristics. Based on the described morphological analysis, different disposition strategies for offshore wind farms can be designed. The consequences of choosing different characteristics were shown in examples. The work presented is the basis for designing a software-based dispositioning tool for usage in offshore wind farms. This software tool will help to increase the effectiveness of the disposition in offshore wind farms by maximizing the number of finished maintenance tasks per day and minimizing the time technicians stay on the wind turbine and the ships. The next steps include the validation of this software tool, in total, during live operation in a wind farm. Further research should be conducted in regards to digitalize and connect the whole data chain, from automatic generation of maintenance tasks to automatic control and disposition of maintenance resources. 


\section{$5 \quad$ References}

1. Siemens AG (2014) Was kostet Offshore- Windenergie wirklich?: Eine makroökonomische Betrachtung

2. Roland Berger Strategy Consultants (2013) Offshore wind toward 2020: On the pathway to cost competitiveness

3. Hirschhausen Cv, Jeske T (2005) Offshore Windenergie: Studie zur Rentabilität von Offshore-Windparks in der Deutschen Nord- und Ostsee. Zeitschrift für Energiewirtschaft : ZfE 29(1): 55-63

4. Schuh G, Brosze T, Brandenburg U (2012) Aachener PPS-Modell. In: Grundlagen der PPS. Springer Vieweg, Berlin [u.a.], pp 11-28

5. Zäpfel G, Bögl M (2008) Multi-period vehicle routing and crew scheduling with outsourcing options. International Journal of Production Economics 113(2): 980996

6. Krug C (2010) Framework zur strategischen Kapazitätsplanung hybrider Leistungsbündel. Zugl.: Bochum, Univ., Diss., 2009. Schriftenreihe des Lehrstuhls für Produktionssysteme / LPS, Ruhr-Universität Bochum, Shaker, Aachen

7. Irawan CA, Ouelhadj D, Jones D et al. (2017) Optimisation of maintenance routing and scheduling for offshore wind farms. European journal of operational research : EJOR 256(1): 76-89

8. Stålhane M, Hvattum LM, Skaar V (2015) Optimization of routing and scheduling of vessels to perform maintenance at offshore wind farms. Energy Procedia 80: 92-99

9. Zwicky F (1966) Entdecken, Erfinden, Forschen im morphologischen Weltbild. Droemer Knaur, München [etc.]

10. Ley W (1984) Entwicklung von Entscheidungshilfen zur Integration der Fertigungshilfmitteldisposition in EDV-gestützte Produktionsplanungs- und -steuerungssysteme. Fortschritt-Berichte der VDI-Zeitschriften. Reihe 02, Betriebstechnik, vol 82. VDI Verlag, Düsseldorf

11. Große-Oetringhaus WF (1974) Fertigungstypologie: Unter dem Gesichtspunkt d. Ferigungsablaufplanung. Betriebswirtschaftliche Forschungsergebnisse, vol 65. Duncker \& Humblot, Berlin

12. Förster H (1988) Integration von flexiblen Fertigungszellen in die PPS. Zugl.: Aachen, Techn. Hochschule, Diss., 1988 u.d.T.: Förster, Hans-Ullrich: Entwicklung von Anforderungen und Gestaltungsvorschlägen zur Integration von flexiblen Fertigungszellen in den Informationsfluß der PPS. Forschung für die Praxis, vol 19. Springer, Berlin

13. Hellingrath B, Witthaut M (2003) Modellierungsrahmen für Dispositionsstrategien in GNL. Technical Report / Sonderforschungsbereich 559 Modellierung großer Netze in der Logistik, Universität Dortmund, vol 03007. SFB 559, Dortmund 